\title{
THERMOLYSED AND ACTIVE YEAST TO REDUCE THE TOXICITY OF AFLATOXIN ${ }^{1}$
}

\author{
Antonio Sampaio Baptista ${ }^{2,5 *}$; Jorge Horiii ; Maria Antonia Calori-Domingues ${ }^{3}$; Eduardo Micotti \\ da Glória ${ }^{3}$; Jocelem Mastrodi Salgado ${ }^{3}$; Mário Roberto Vizioli ${ }^{4}$ \\ ${ }_{3}^{2}$ Pós-Graduanda em Microbiologia Agrícola - USP/ESALQ. \\ ${ }^{3}$ Depto. de Agroindústria, Alimentos e Nutrição - USP/ESALQ, C.P. 9 - CEP: 13418-900 - Piracicaba, SP. \\ ${ }_{5}^{4}$ Depto. de Diagnóstico Oral - FOP/UNICAMP, C.P. 52 - CEP: 13414-903 - Piracicaba, SP. \\ ${ }^{5}$ CAPES Fellow. \\ *Corresponding author <asbaptis@carpa.ciagri.usp.br>
}

ABSTRACT: Aflatoxins are hepatotoxic metabolites produced by Aspergillus flavus and A. parasiticus on a number of agricultural commodities. This research was carried out to evaluate the ability of thermolysed and active Saccharomyces cerevisiae to attenuate liver damage caused by aflatoxin. Diets were prepared containing 0 aflatoxin; $400 \mu \mathrm{g} \mathrm{kg}^{-1}$ aflatoxin; $400 \mu \mathrm{g} \mathrm{kg}{ }^{-1}$ aflatoxin plus $1 \%$ of dehydrated active yeast, and $400 \mu \mathrm{g} \mathrm{kg}^{-1}$ aflatoxin plus $1 \%$ of thermolysed yeast. A bioassay with Wistar rats was conducted for 28 days, and body organs were weighted and analyses of the liver tissue of the animals were performed. The relative weight of heart, kidneys and liver from animals submitted to the different treatments did not show any difference, and liver tissue of animals feeding on the aflatoxin-free diet was adopted as a toxicity-free pattern. Hepatic tissue of animals feeding on diets containing $400 \mu \mathrm{g} \mathrm{kg}{ }^{-1}$ aflatoxin or the diet supplemented with $1 \%$ thermolysed yeast showed clear signs of toxicity and damage. Hepatic tissue of animals feeding on the diet containing $1 \%$ of dehydrated active yeast showed less toxicity signs and damage than those receiving the diet containing $400 \mu \mathrm{g} \mathrm{kg}^{-1}$ aflatoxin. Active, dehydrated yeast had the ability to reduce toxic effects caused by aflatoxin, but thermolysed yeast was not able to alleviate the effects of aflatoxin toxicity.

Key words: Saccharomyces cerevisiae, aflatoxicosis, bioremediation, mycotoxins, natural contamination

\section{FORMAS TERMOLISADA E VIVA DE LEVEDURAS NA REDUÇÃO DE TOXICIDADE CAUSADA POR AFLATOXINAS}

\begin{abstract}
RESUMO: As aflatoxinas são metabólitos hepatotóxicos produzidos por algumas linhagens de Aspergillus flavus, A. parasiticus e, eventualmente, por A. nomius sobre grande número de produtos agrícolas. Esta pesquisa foi conduzida para avaliar a capacidade de Saccharomyces cerevisiae, nas formas termolisada e desidratada viva, em reduzir os danos causados por aflatoxinas. Para tal, foi preparada uma dieta básica e desta se obtiveram quatro formulações: uma como controle; as demais contaminadas com aflatoxinas na concentração de $400 \mu \mathrm{g} \mathrm{kg}^{-1}$, sendo duas com posterior adição de $1 \%$ de leveduras, uma na forma termolisada e outra como desidratada viva. Um bioensaio com duração de 28 dias foi efetuado com ratos Wistar. Foram realizados os estudos do peso relativo de órgãos internos e a análise do tecido hepático dos animais. Os pesos relativos de órgãos internos de animais submetidos aos diferentes tratamentos não diferiram estatísticamente entre si; o tecido do fígado dos animais submetidos à dieta livre de aflatoxinas foi adotado como padrão de isento de toxidez; o tecido hepático dos animais que receberam dieta controle com aflatoxinas apresentaram sinais claros de toxicidade; os animais que receberam dieta com aflatoxinas $+1 \%$ de levedura termolisada apresentaram sinais de toxicidade semelhantes ao controle com aflatoxinas; o tecido hepático dos animais que receberam dieta com aflatoxinas $+1 \%$ de levedura viva apresentaram sinais de toxicidade menores do que os animais que receberam a dieta controle com aflatoxinas. As leveduras termolisadas não foram capazes de suprimir os efeitos das aflatoxinas; as leveduras vivas apresentaram habilidade de reduzir os efeitos promovidos por aflatoxinas.
\end{abstract}

Palavras-chave: Saccharomyces cerevisiae, aflatoxicoses, biorremediação, contaminação natural, micotoxinas

\section{INTRODUCTION}

Basic ingredients and dietary supplements of an animal diet may have functional proprieties in the diet, i.e., such as a nutraceutical supplement. Among several dietary supplements studied as a nutraceutical additive, yeast, especially, Saccharomyces cerevisiae, has shown satisfactory results when added to rations as active cells or cell wall components (Stanley et al., 1993; Spring,
2000). Yeast has a well-balanced amino acid composition and high contents of lysine, methionine and threonine. In addition, the content of essential amino acids in yeast is to the values recommended by the FAO (Rose \& Harrison, 1970; FAO/ WHO/ ONU, 1985).

The addition of low quantities (0.1-2.0\%) of active yeast to an animal ration can stimulate the growth of intestinal bacteria. As a consequence, nutrients breakdown will be more efficient and the animals will be

${ }^{1}$ Part of the Ms.Sc.Dissertation of the first author, presented to USP/ESALQ - Piracicaba, SP. 
able to uptake higher amounts of proteins, i. e. nitrogen, and energy from the diet (Dawson, 1993).

On the other hand, the economic impact of aflatoxin contamination occurs at all levels of plant and animal production, at various commercial stages, comprising both products and by-products (Kubena et al., 1990). Losses caused by aflatoxin contamination are associated with the frequency of contamination of agricultural products and to the time of exposure of animals to chronic levels of these compounds through the intake of contaminated rations or feed (Hamilton, 1984).

Increasing methionine contents in diets of domestic animals contributed to lower aflatoxin toxicity effects in comparison to diets without amino acid supplementation (Schmith \& Moss, 1985) . Therefore, it is fair to infer that absorption of methionine in the intestine might play an important role in suppressing aflatoxin effects in supplemented diets. Moreover, Stanley et al. (1993) showed that live yeast added to the diet contaminated with aflatoxin is able to suppress the harmful effects of this toxin in animals.

Nothing has been documented in Brazil regarding the influence of live yeast as a dietary supplement in animal feeds. Therefore, the objective of this study was to analyze the ability of thermolysed or active $S$. cerevisiae to reduce aflatoxicosis damages in laboratory rodents.

\section{MATERIAL AND METHODS}

Wistar rats (Rattus norvegicus), 21- to 25-day-old, were housed in 20 cages, and separated in four groups of five animals to evaluate the severity of aflatoxin toxicity and the interaction of thermolysed and active $S$. cerevisiae added to their feed. The trial was set up in a completely randomized design with four treatments $(n=5)$, represented by four different diets: A basal, casein-based $\geq 85 \%$ of protein, aflatoxin-free diet (Non- Detectable Levels $=0.5$ $\mu \mathrm{kg}^{-1}$ ) - diet AIN-93G described by Reeves et al (1993) - and three aflatoxin-contaminated diets $\left(400 \mu \mathrm{g} \mathrm{kg}^{-1}\right)$, one of them supplemented with $1 \%$ thermolysed yeast and the other with $1 \%$ active yeast.

Aflatoxin was introduced in the diets through the addition of $20 \%$ peanuts, naturally contaminated with aflatoxin. All diets were stored in a refrigerator prior to using. Daily ration of each animal was $15 \mathrm{~g}$ of feed and water "ad libitum", for a experimental period of 28 days.

Two different types of Saccharomyces cerevisiae were used to supplement the diets: Strain Y1026 in active, dehydrated form, and a non-characterized, thermolysed yeast strain. The viability of yeast cells was determined utilizing the methylene blue $(0.1 \%)$ staining method (Pierce, 1970). Active yeast cells averaged $80 \%$ viability at the time of the experiment. The determination of aflatoxin was conducted by bi-directional thin layer chromatography (Soares \& Rodrigues-Amaya, 1989) with a detection limit of aflatoxins at $0.5 \mu \mathrm{g} \mathrm{kg}^{-1}$.

After 28 days, animals were terminated in an ether-saturated chamber saturated and the internal organs were excised from their body cavities. Heart, kidneys and liver were fixed in $10 \%$ formaldehyde. Analyses of tissues were conducted as described by Pacheco (1981). Tissue sections were stained with hematoxylin and eosin. Slides were analyzed by light microscopy for the presence or absence of aflatoxin toxicity symptoms (magnification at $200 \mathrm{x}$ ). Hepatic tissue from animals feeding on aflatoxinfree diet was considered toxicity-free standard. Data collected were submitted to the analysis of variance and to the Tukey's test for mean comparison.

\section{RESULTS AND DISCUSSION}

Relative weights of heart, kidneys and liver from the animals fed the four different diets did not differ statistically $(P<0,05)$ (Table 1). The concentration and the period of exposure of animals to aflatoxin was not enough to cause significant differences in the weights of examined body organs. These results do not corroborate those found by Stanley et al. (1993), who reported that chickens ingesting $5 \mathrm{mg} \mathrm{kg}^{-1}$ of aflatoxin for 28 days had heart, kidneys and liver weights higher than those recorded for chickens receiving aflatoxin-free diets for the same period.

Possible reasons for these different results are that the amount of aflatoxin added to the diets in boths studies. Chickens ingested $5 \mathrm{mg} \mathrm{kg}^{-1}$ of diet, while rats ingested $400 \mu \mathrm{g} \mathrm{kg}^{-1}$ for the same period of time. In addition, rats are naturally more resistant to aflatoxin (Barnes \& Butler, 1964).

Liver tissue from animals receiving the caseinbased, aflatoxin-free diet did not show proliferation of the bile ducts which is, characterized by the presence of clear patches within areas of long irregular vesicles (Figure 1a). However, a small number of circular, clear regions (vacuoles) were observed in the liver of animals feeding on the basal diet. These regions were considered normal because the rats were overweight at the end of

Table 1 - Comparison of the weights of body organs of the rats feeding on the experimental diets.

\begin{tabular}{|c|c|c|c|}
\hline Treatment & Liver & Heart & Kidneys \\
\hline & \multicolumn{3}{|c|}{ grams per 100 grams of fresh weight } \\
\hline Basal diet (casein-based, aflatoxin-free) (T1) & 3,26 a & 0,46 a & 0,94 a \\
\hline Basal diet $+400 \mu \mathrm{g} \mathrm{kg}^{-1}$ aflatoxin (T2) & 3,46 a & $0,41 \mathrm{a}$ & 0,79 a \\
\hline Basal diet $+400 \mu \mathrm{g} \mathrm{kg}^{-1}$ aflatoxin $+1 \%$ of thermolysed yeast (T3) & 3,63 a & 0,44 a & 0,77 a \\
\hline Basal diet $+400 \mu \mathrm{g} \mathrm{kg}^{-1}$ aflatoxin $+1 \%$ of active yeast (T4) & 3,66 a & $0,44 \mathrm{a}$ & 0,78 a \\
\hline
\end{tabular}

Means within a column followed by same superscript do not differ by Tukey test $(p<0.05)$. 
the experiments. Vacuolation can easily occur in hepatic tissue of obese animals, since fats or lipids can cause modifications in the cellular homeostasis. Therefore, the observation of vacuolation on sampled liver tissue was considered normal because animals feeding on the basal diet presented high deposition of lipids. Comparison to tissue sampled from animals feeding on a diet containing aflatoxin, allowed to estimate the degree of toxicity.

Figure $1 \mathrm{~b}$ illustrates the profile of hepatic tissue of animals receiving the diet containing $400 \mu \mathrm{g} \mathrm{kg}^{-1}$ aflatoxin, which shows extensive proliferation of bile ducts, a sign of irreversible toxicity caused by aflatoxin and may lead to cell death. Typical vacuolation can also result from

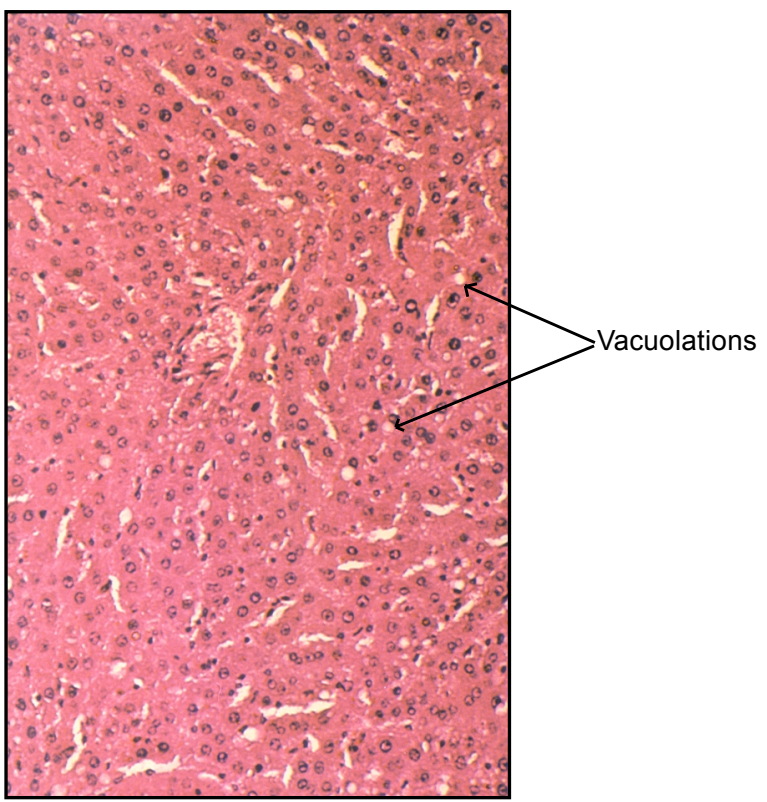

Figure 1a - Photomicrograph of hepatic tissue of Wistar rats fed on a aflatoxin-free, casein-based diet (Magnification $200 \mathrm{x})$.

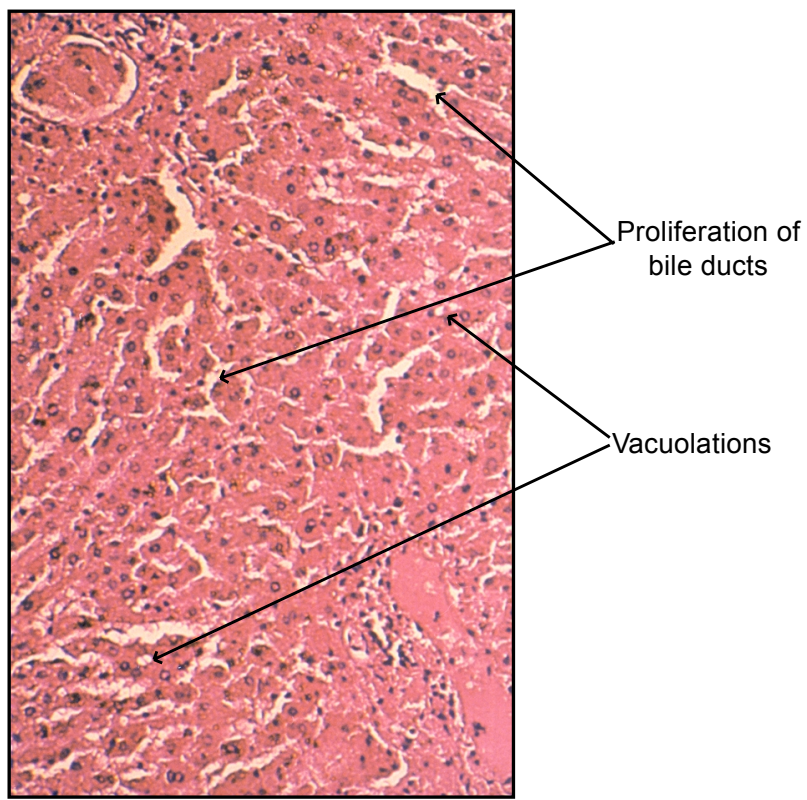

Figure 1c - Photomicrograph of hepatic tissue of Wistar rats fed on a diet containing $400 \mu \mathrm{g} \mathrm{kg}^{-1}$ of aflatoxin and $1.0 \%$ of thermolysed yeast (Magnification $200 \mathrm{x}$ ). aflatoxin toxicity. These findings corroborate with those described by Robbins et al. (1986), who reported that even though alteration in the lipid or fat content can be reversible, irreversible lesions can lead to cell death.

Results on accumulation of lipids in the hepatic tissue of animals receiving diets containing $400 \mu \mathrm{g} \mathrm{kg}^{-1}$ aflatoxin are similar to data reported by Wogan (1973), Rodricks \& Stoloff (1977), and Heathcote \& Hibbert (1978). These authors hypothesized that alterations in carbohydrate metabolism caused by the presence of aflatoxin lower glucose concentration and alter lipid transport routes, causing a preferential lipid synthesis in the hepatic cells and deposition of lipids.

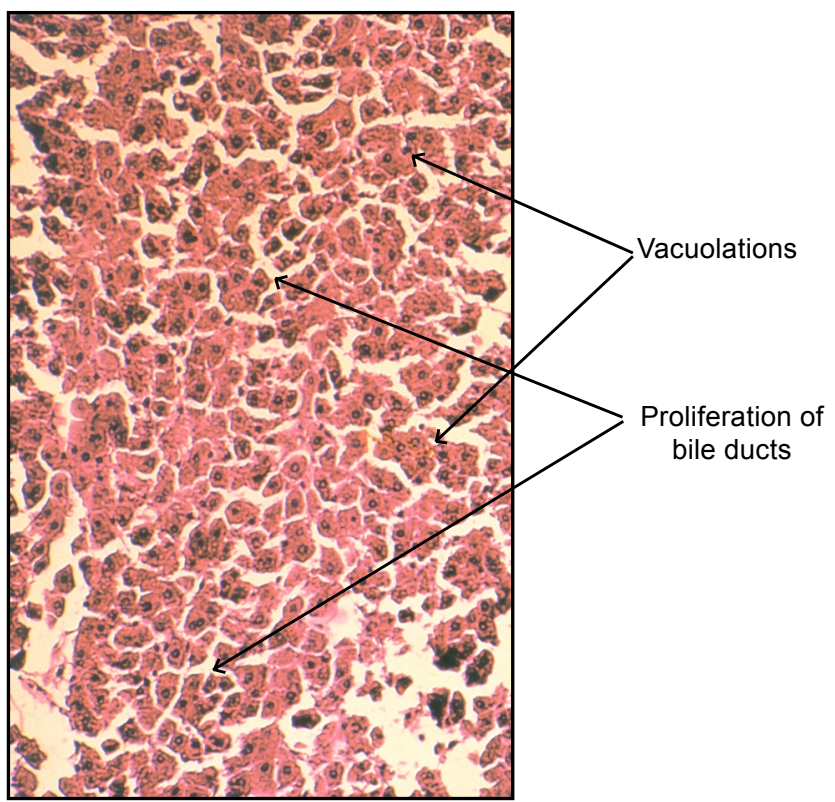

Figure $1 \mathrm{~b}$ - Photomicrograph of hepatic tissue of Wistar rats fed on a diet containing $400 \mu \mathrm{g} \mathrm{kg}^{-1}$ of aflatoxin (Magnification $200 \mathrm{x})$.

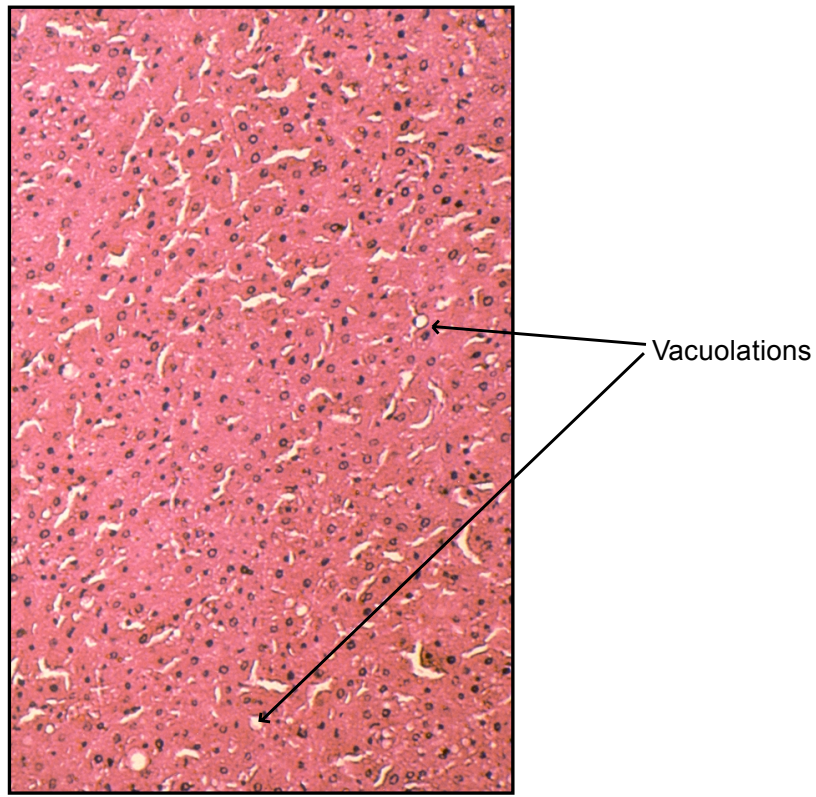

Figure $1 \mathrm{~d}$ - Photomicrograph of hepatic tissue of Wistar rats fed on a diet containing $400 \mu \mathrm{g} \mathrm{kg}^{-1}$ of aflatoxin and $1.0 \%$ of dehydrated active yeast (Magnification $200 \mathrm{x}$ ). 
Histological analyses of samples from animals receiving basal diet $+400 \mu \mathrm{g} \mathrm{kg}^{-1}$ aflatoxin $+1 \%$ of thermolysed yeast (Figure 1c), revealed the formation of several vesicles (vacuolation) and proliferations of bile ducts, probably caused by the accumulation of lipid, and signs of non-reversible lesions that could lead to cell death. These signs were similar to those found in the hepatic tissue of animals feeding on diets containing $400 \mathrm{\mu g} \mathrm{kg}^{-1}$ aflatoxin.

Presence of thermolysed yeast did not limit the cell damage caused by aflatoxin (Figure 1c). However, the presence of the polysaccharide mannan in the yeast cell wall can incite the animal immunological system and suppress intestinal pathogenic bacteria (Dawson \& Pirvulescu, 1999; Finucane et al., 1999), thus reducing the animal weight loss caused by the activity of intestinal inhabiting harmful microorganism.

Hepatic tissue from animals receiving the diet containing $400 \mu \mathrm{g} \mathrm{kg}^{-1}$ aflatoxin $+1 \%$ of active yeast showed that aflatoxin toxicity signals were very mild when compared to those observed in animals receiving the diet containing $400 \mu \mathrm{g} \mathrm{kg}^{-1}$ aflatoxin alone (Figure 1d). The presence of active yeast in the diet alleviated the aflatoxicosis signals. These findings corroborate with those reported by Stanley et al. (1993), who fed chickens with a diet containing $5 \mathrm{mg} \mathrm{kg}^{-1}$ of aflatoxin but supplemented with $0.1 \%$ live yeast for 28 days, and observed that the animals showed mild aflatoxicosis symptoms when compared to those fed a diet containing aflatoxin alone.

Several hypotheses explain the ability of active yeast to alleviate the aflatoxicosis effects. It is possible that $S$. cerevisiae represses the aflatoxicosis severity via chelating aflatoxin, which is transported to and eliminated via intestinal tract (Cooney, 1980). Because it is a source of vitamins, non-identified growth factors, proteins and enzymes, yeast is also known to lower stress in animals (Crumplen et al., 1989). Furthermore, Sullivan et al (1978) documented that the addition of yeast to a aflatoxin-containing diet causes an increase in enzymes that modify the aflatoxin effects. The importance and potential of enzymes produced by certain microorganisms to decontaminate aflatoxicosis was documented by Mgbodile et al. (1975), and later confirmed by Dalvi \& McGowan (1984), who concluded that enzymes can stimulate the bio-transformation of a few toxins in vivo, thus altering the duration and intensity of the toxic effects.

\section{CONCLUSIONS}

Thermolysed yeast did not alleviate the aflatoxin toxicity symptoms in the hepatic tissue of rats, while dehydrated active yeast was able to reduce the hepatotoxicity caused by aflatoxin in hepatocytes.

\section{ACKNOWLEDGMENTS}

To Maria Lourdes Stors, from the Laboratory of Nutrition USP/ESALQ/LAN, for the helping with the bioassays; Ivani V. Zambello, from the Mycotoxin Laboratory USP/ESALQ/LAN, who helped with the aflatoxin analyses, and Alltech do Brasil and the sugar cane plant "Galo Bravo", Ribeirão Preto, SP, for providing the yeast strains.

\section{REFERENCES}

BARNES, J.M.; BUTLER, W.H. Carcinogenisis activity of aflatoxin in rats. Nature, v.202, p.1016, 1964.

COONEY, D. O. Activated charcoal: antidotal and other medical uses. New York: Marcel Dekker, 1980.

CRUMPLEN, R.; D'AMORE, T.; PANCHAL, C.J.; RUSSELL, I.; STEWART, G.G. Industrial uses of yeast: present and future. Yeast, v.5, p.3-9, 1989

DALVI, R.R.; McGOWAN, C. Experimental induction of chronic aflatoxicosis in chickens by purified aflatoxin $B_{1}$ and its reversal by activated charcoal, phenobarbitol, and reduced glutathione. Poultry Science, v.63, p.485491, 1984.

DAWSON, K.A. Current and future role of yeast culture in animal production: a review of research over the last seven years. In: BIOTECHNOLOGY IN THE FEED INDUSTRY, 9., New York, 1993. Proceedings. New York: ABFI, 1993. p.21

DAWSON, K.A.; PIRVULESCU, M. Mananoligossacarídeos derivados de leveduras como moduladores da resposta imunológica e alternativa aos promotores de crescimento antimicrobianos. In: RONDA LATINOAMERICANA DA ALLTECH, 9., Campinas, 1999. Anais. Campinas: Altech, 1999. p.33-41.

$\mathrm{FAO} / \mathrm{WHO} / \mathrm{ONU}$. Energy and protein requirements. Geneva, 1985. (Report, 724).

FINUCANE, M.P.; SPRING, P.; NEWMAN, K.E. Incidence of mannose sensitive adhesins in enteric pathogens. In: SOUTHERN POULTRY SCIENCE, 18., Atlanta, 1999. Poster. Atlanta, 1999. p.21.

HAMILTON, P.B. Determining safe concentrations of mycotoxins. Journal of Food Protection, v.47, p.570-575, 1984.

HEATHCOTE, J.G.; HIBBERT, J.R. Aflatoxins: chemical and biological aspects. New York: Elsevier Science, 1978.

KUBENA, L.E.; HARVEY, R.B.; PHILLIPS, T.D.; CORRIER, D.E.; HUFF, W. E. Diminution of aflatoxicosis in growing chickens by the dietary addition of a hydrated sodium calcium aluminosilicate. Poultry Science, v.69, p.727-735, 1990.

MGBODILE, M.U.K.; HOLSCHER, M.; NEAL, R.A. Possible protective role for reduced glutathione in Aflatoxin $B_{1}$ toxicity: effect of pretreatment of rats with phenobarbitol and 3-methylchoranthrene on aflatoxin toxicity. Toxicology and Applied Pharmacology, v.34, p.128-142, 1975

PACHECO, A.C. Compêndio básico de técnicas histológicas. Botucatu: Universidade Estadual Paulista "Júlio de Mesquita Filho", 1981. 30p.

PIERCE, J.S. Analysis committee: measurement of yeast viability. Journal of the Institute of Brewing, v.76, p.442-443, 1970.

REEVES, P.G.; NIELSEN, F.H.; FAHEY, G.C. Ain-93 purified diets for laboratory rodents - final report of the American Institute of Nutrition ad hoc writing committee on the reformulation of the ain-76a rodent diet. Journal of Nutrition, v.23, p.1939-1951, 1993.

ROBBINS, S.L.; ANGELL, M.; KUMAR, V. A doença em nível celular. In: ROBBINS, S.L.; ANGELL, M.; KUMAR, V. (Ed.) Patologia básica. São Paulo: Ateneu, 1986. cap.1, p.3-31.

RODRICKS, J.V.; STOLOFF, L. Aflatoxins residues from contaminated feed in edible tissues of food-producing animals. In: RODRICKS, J.V.C.; HESSELTINE, W.; MEHLMAN, M.A. (Ed.) Mycotoxins in human and animal health. Park Forest South: Patholox Publishers, 1977. cap.3, p.67-69.

ROSE, A.H.; HARRISON, J.N. The yeasts. London: Academic Press, 1970. v.3, 590p.

SCHMITH, J.E.; MOSS M.O. Mycotoxins: formation, analysis and significance. New York: Chichester, 1985. 148p.

SOARES, L.M.V.; RODRIGUES-AMAYA, D.B. Survey of aflatoxins, ochratoxin $A$, zearalenone and sterigmatocystin in some Brazilian food by using multitoxin thin-layer chromatographic method. Journal of Official Analytical Chemists, v.72, p.22-26, 1989.

SPRING, P. Yeast's secret weapon aids animal production. In: SIMPÓSIO SOBRE ADITIVOS ALTERNATIVOS NA NUTRIÇÃO ANIMAL, Campinas, 2000. Anais. Campinas: CBNA, 2000. p.44-55.

STANLEY, V.G.; OJO, R.; WOLDESENBET, S.; HUTCHINSON, D.H.; KUBENA, L.F. The use of Saccharomyces cerevisiae to suppress the effects of aflatoxicosis in broiler chicks. Poultry Science, v.72, p.1867-1872, 1993.

SULLIVAN, T.W.; KUHL, H.J.; HOLDER, D.P. Evaluation of Brewer's dried grain yeast in turkey diets. Poultry Science, v.57, p.1329-1336, 1978.

WOGAN, G.N. Aflatoxin carcinogenesis. Methods of Cancer Research, v.7, p.303-344, 1973.

Received April 02, 2001 